\title{
Folklore Source and Fiction texts
}

\author{
Assoc. Professor Ketevan Barbakadze, Doctor of Pedagogics
}

Professor Tamar Gogoladze, Doctor of Philology

\begin{abstract}
During a period of time the folklore source has not always become a plot of a national or foreign text. The main point is the theme of folklore source. The myth of antique epoch about Leander and Hero's tragic love appeared to be one of such themes reflected in the world Literature (Ovidius, Musées, Schiller, Grillparzer, Byron, Kuprin). At the same time "The Poem of the Lad from Tavparavani", very popular in Georgian folklore, the subject matter of which is very close to the Greek myth. The mentioned ballade became a story-line of two Georgian fictions (G. Dochanashvili and T. Chiladze). In the literary and folklore studies of 30s of the XX century, the similarity of the subject matter provoked the idea of originating "The Poem of the Lad from Tavparavani" from a Greek myth, though the idea appeared less proved for us. That is why, we have tried to broaden thoughts and ideas of some Georgian researchers (V. Kotetishvili, G. Kalandadze) concerning the authentic origin (arisen on the Georgian basis) of "The poem of the Lad from Tavparavani". After that to state the issue, which is based on using a plot of folklore, source in fictions where the reality of arising on national basis is proved.

The current research represents a modest attempt to research the origins of "The Poem of the Lad from Tavparavani", which is represented in the Georgian fictional works (G. Dochanashvili; T. Tchiladze) and proves its authenticity (Georgian origins), which on the one hand bears an utmost importance for the development of Georgian folkloristic and one the other hand represents a potential learning resource for high school and university students.
\end{abstract}

Keywords : Folklore, Myth, Tavparavani, Discourse, Literature.

\section{Introduction}

During a period of time the folklore source has not always become a plot of a national or foreign text. The main point is the theme of folklore source. The myth of antique epoch about Leander and Hero's tragic love appeared to be one of such themes reflected in the world Literature (Ovidius, Musées, Schiller, Grillparzer, Byron, Kuprin). At the same time "The Poem of the Lad from Tavparavani", very popular in Georgian folklore, the subject matter of which is very close to the Greek myth. The mentioned ballade became a story-line of two Georgian fictions (G. Dochanashvili and T. Chiladze). In the literary and folklore studies of 30s of the XX century, the similarity of the subject matter provoked the idea of originating "The Poem of the Lad from Tavparavani" from a Greek myth, though the idea appeared less proved for us. That is why, we have tried to broaden thoughts and ideas of some Georgian researchers (V. Kotetishvili, G. Kalandadze) concerning the authentic origin (arisen on the Georgian basis) of "The poem of the Lad from Tavparavani". After that to state the issue, which is based on using a plot of folklore, source in fictions where the reality of arising on national basis is proved. 


\section{Discourse of the Folklore Source and fictional texts}

In the world folklore, a subject matter rarely represents a fascinating material coming from the theme that may have come to literature since the oldest period due to trading and cultural relations either from East or from West. In the 70s of the XIX century Spreading wide the theory of "borrowing" in Georgia, promoted accepting some samples of orally transmitted folklore (mainly myths, ballades and fairy-tales) as brought in from other folklore. However, the circumstance of transforming a brought in sample into a national creative work based on working it out can be undeniable. This factor makes difficult to state the authenticity of the folklore sample as Georgian culture was arisen on the origin that represented the crossroad where Eastern or Western orally transmitted folklore were introduced during centuries due to political or trading reasons. The followers of the "borrowing theory" that is Benefits factually examined folklore samples separately, not taking into consideration the national roots. That is why they brought them down to schemes of the subject matters. At the same time, opposing the "borrowing theory" anthropological theory or self-conceiving theory is broadening in Georgian reality. According to Taylor the similarity of subject matters could be caused by the similarity of people's nature, psyche and objective reality. The culture and creative works of people living in the same conditions though being far apart from each other could be similar as the development was going on according to the same scheme" (Kurdovanidze, 201:212). Just on the basis of this theory the new way of explaining the subject matters of fairy tales became possible. The creator of historical school of folklore study Vsevolod Miller tried to study Russian Bylines in connection with the history and connected their origin to the past of the nation of orally transmitted folklore. This theory also became very popular in Georgia and during folkloristic analysis of "The Poem of the Lad from Tavparavani" the "borrowing theory influenced connecting its origin to the Greek myth about Leander and Hero and the study of the folkloristic samples was going through discussion about the similarity of the subject matters or originating it from Greek. (M. Kakabadze, T. Makhauri, I. Merabishvili, I. Adamia etc). A kind of stereotype was formed: "The poem of the Lad from Tavparavani", 16 records of which has existed in East Georgia since 1882, was mentioned as a variety of a Greek myth.

It is noteworthy to state the fact that in the XX century just this ballade ("The Poem of the Lad from Tavparavani) became the basis of two fictions: "The Lad from Tavparavani" by Guram Dochanashvi (prose) and "The Ballade of Tavparavani" by Tamaz Chiladze, (a three-acted play-fairy tale). While working on these the article* "The Mythical Sketch of the Lad from Tavparavani in Modern Fiction (G. Dochanashvili, T. Chiladze) was created.

Comparing Georgian fictions to fictions created on the theme of Leander and Hero will give us opportunity to strengthen the doubts of three researchers about the Georgian origin of "The Poem of the Lad form Tavparavani". "Above mentioned Greek myth about Hero and Leander, remained in the folklore and literature of Rome or Germany, makes clear the relations with our folk-tale. Not even the plot, but even

\footnotetext{
* The article "The Mythical Sketch of the Lad from Tavparavani in Modern Fiction (G. Dochanashvili, T. Chiladze) was presented in the X International Conference of Gori State Teaching University (17-18 November, 2017). It exists in the form of a manuscript.
} 
the subject matters coincide with each other but the issue starts beyond these parallels. Namely: what type of folk-tale it is and where to search its origin" (V. Kotetishvili, 1963:332). "The existence of the Greek Myth and its spread in the western literature does not mean that the subject matter of "The Poem of Lad from Tavparavani" is imported and is not original Georgian. The motif of crossing a rough sea to the beauty's tower by a handsome fellow in Georgian Folk tales is very popular and this could have become a poetical inspiration for a teller of a Georgian ballade. (G. Kalandadze, 1957:93-94)

Just on the bases of discussing the recorded folk drama of "The Lad from Tavparavani" D. Janelidze remarks: "Many parallels to "The Lad from Tavparavani" can be found. This tragedy has the oldest myths in origin and it finds its origins in the cult of Sea and the Moon. This proves that in the folk tragedy recoded by Ia Kargareteli, the spirit, its theme and the tradition of its dramatic personification how modernized it could be, are still kept" (D. Janelidze, 1948:145).

Folklore sources and fictions are presented for study. Typological analysis of Georgian and foreign fictions will promote a rapid study of this issue. I. Adamia controversies this issue and tries to export this folk-tale in a changed way.

Before making conclusions about the authenticity of "The Poem of the Lad from Tavparavani" it is necessary to get acquainted with the folklore sources which had been done several times by different researchers to find out the similarity of subject matters.

The subject matter of Hero and Leander (Leander and Hero) is as follows: on the one side of Hellespont on the beach of Troad (Troada) Leandro, a lad from Abydos, fell in love with Hero, a daughter of pagan priest, Sestos, who lived on the other side at the beach of strait. Every night Hero lit a torch on the top of the top of the tower and the lad from Abydos swam to the tower through this light, met his beloved until dawn and then returned. One night wind blew out the torch, the lad drowned in fierce waves, and on the next day, his corps was washed ashore at the tower. Hero screamed and jumped down from the edge of the tower. In the "Mythological Dictionary" by Akaki Gelovani (2016) it is underlined that this love ballade must belong to the cult of Dionysus - to the oldest cycle of sea deity. A Roman elegist Publius Ovidius Nazon (43 B.C - 8 A.D) gave place to correspondence between Leander and Hero among the love letters of mythological Heroines (written to husbands or sweethearts) in his collection of creative works "Heroides". This could have been the first feature epistolary text dedicated to the oldest Greek myth.

"The Poem of the Lad from Tavparavani" first was recorded in 1882 in Dusheti region, in East Georgia; other versions mainly are found by the collectors of orally transmitted folklorists in various regions of east Georgia (Kartli, Kakheti, Pshavi, Pankisi, Khevi, Samtskhe-Javakheti). By the folklore text from Tavparavani (location should be pointed, the origin of the lad, grand lake "Tavparavani" or "Paravani" existing in Samtskhe -Javakheti). In some versions with the love a young woman, living across the Black Sea, in Akhkardo (Aspindza, Chashka, Sapara) every night the lad swam across the water and the way was lit by the candle from the window of the lady. One day a witch extinguished the candle. The lad could not find his way through darkness and drowned. The next morning his corps was washed ashore which was followed by the dreadful morn of the young woman. 
An American Kartvelologist Kevin Tuite and A Georgian scientist of Byron studies Innes Merabishvili translated one of the spread versions of the text.

\section{The Lad From Tavparavani}

A lad from Tavparavani,

Was loved by a maid of Aspindza.

He had a wide sea to cross,

But in no wise was he daunted.

The woman had lighted a candle;

The candle sent forth its beam.

A certain evil-souled crone

Plotted the young man's destruction.

The taper that gleamed in the window

She snuffed out, to bring him to grief.

And said to herself as she did so:

"Did not this boy once love you?"

The young man cut through the waves,

His heart and lungs were not strained.

With one hand he held a millstone,

With the other he swam the sea.

From over the water a candle

Shed light to the other side;

By now the night had fallen,

A night dark as blackest pitch.

Wave pounded on wave

And strove to make the lad drown.

He lost his guide-beam, was confounded;

Before him a whirlpool roared ...

The morning dawned bright and cheery,

Bright as a gay maiden's eyes.

The waters had drowned the young man.

He drifted ashore at Aspindza.

His red shirt of finest silk

Fluttered in the soft breeze;

An eagle perched on his corpse,

Tore at his heart and was sated

(Translated by Kevin Tuite)

\section{A Handsome Lad of Paravani}

A handsome lad of Paravani

In love with a maid of Aspara

Was never daunted to mount huge waves

Across the sea to meet his lover.

The maid would always light a candle, 
The candle shone as a small marvel.

An ugly crone of wicked soul

Intended evil for the couple.

She, when in fury, reached the casement,

Snuffed out the light to harm, to humble,

The wicked crone to her oft murmured:

You ever had the same lover.

By then the lad met billows high,

His breast heaved smoothly, had no trouble,

With one hand carried he a lifebelt

And wafted the air with his other.

A single candle on one bank

Could well throw light on the other.

But moonless night came o'er the lake

With total darkness all to cover.

And wave on wave did pound him strongly

To swallow up, devour the lover.

He lost the ford, the storm was raging,

The toil for him became thus harder.

The morning broke so full of beauty

Like eyes of damsels fair that sparkle.

The lad was drowned, his lifeless body

Moved smoothly floating on the shallows.

And near the shore of small Aspara

His crimson shirt did lonely flutter.

His loving heart, his poor young body

Were torn up gaily by a vulture."

A famous folklorist Tristan Makhauri presented comparison of two myths (German "The Prince and the Princess" and "The Poem of the Lad from Tavparavani"). "Different Georgian researchers discuss the similarity of subject matters of the mentioned ballades (besides Akaki Gelovani, Mikheil Chikovani, Giorgi Kalandadze), but none of the Georgian folklorists have made a structural analysis of these ballades" (T. Makhauri, 2011:17). As a result of comparison T. Makhauri concludes: "Despite the similarity in the subject matters of theses ballades we come across different moments and just the similarity gives originality to these two works." (T. Makhauri, 2011:20)

Despite the brilliant attempt of comparison, the conclusion seems somehow vague and what is more, our topic concerns "the myth of Hero and Leander" and "The Poem of the Lad from Tavparavani"

It is clear that the subject matters of both folk sources are almost equal. That is why since 30s of the XX century the researchers (V. Kotetishvili) started either from the Greek myth and finished with "The Poem of the lad from Tavparavani" or vice versa. In addition, this was done in order to reject the authenticity of "Tavparavani" which

${ }^{*}$ Translated by Innes Merabilshvili. 
was not simply aimed, while discussing the knowledge of the scientists "Tavparavani" urged them to make analog between them.

"Even reading the poem superficially the reader will feel something fantastic and fairy country. The poem is very close to love lyrics but it has remained several documents, which clarify the parts of mythos, and their oldness kept in the poem. According to the document remained in the poem would have even become stronger stating its nature and character if it have not been the parallels with the world literature. By means of these parallels the vague symbolic of our poem is revealed which cannot be explained only in Georgian" (V. Kotetishvili 1961:329)

Observing V. Kotetishvili's manner of discussion it can be explained why Georgian researchers are trying to look for the analog with the Greek myth. This in many cases makes even vaguer the authenticity of "Tavparavani". In addition, Kotetishvili himself presents the work of a researcher and poet Vyacheslav Ivanov ("Dionysus and Pre-Dionysus" 1923). According to this work the myth about Hero and Leander could be connected to the cult of Dionysus and the Lady with a lantern is a symbol of the Moon, Leander is a symbol of dolphin which are the names of Sea Dionysus (all swimmers, "antika Taucher" V.K)

That is why V. Kotetishvili's conclusion is connected to the cult of Dionysus and the prefix "tav" in the "Tavparavani" is concerned as a sign of mythos.

Form the above mentioned we consider V. Kotetisgvili's conclusion more noteworthy: the oldest sign of mythos and the necessity of deepening into its roots.

For the researcher Manana Kakabadze it is clear that the theme of lad from Tavparavani is very old from its origin but considers "Hero and Leander" as a Georgian version of "The Lad from Tavparavani". The existence of Georgian version of the legend of the world importance is very significant for seeking the romantic elements of Georgian poetic folklore. (M. Kakabadze, 2008)

A.Gelovani agrees with V. Kotetishvili's point of view of considering "The Lad from Tavparavani" as a Georgian name of Sea God Dionysus. A researcher and translatorInnes Merabilshvili in her letter "Translation as a Lexicographical Research (on the Example of One Word)" talks about the translation of the Georgian ballade made by Kevi Tuite. She portrays the fact of crossing Hellespont by swimming in May 3 of 1810 and later mentions: "The Georgian parallel of this myth "The Lad from Tavparavani" is very noteworthy and interesting as a pearl of Georgian folk poetry" (I. Merabishvili, 2011:159). So, researchers note the parallel between "Hero and Leander" and "The Poem of Lad from Tavparavani" still cannot openly talk about the authenticity of the Georgian creature the bases of which on the stage of our research can give both featured texts created on folk sources.

For comparison, we can address to "The Bride of Abydos" by Byron, "Hero, Leander and The Shepard" by Kuprin (1929) - from foreign literature and from Georgian texts a story "The Lad from Tavparavani" by G. Dochanashvili and a fairy-tale "A Ballade of Tavparavani” by T. Chiladze. 
"The Bride of Abydos" by Byron is a poem and does not represent a direct literary worked our version of a myth though as researchers note the realis of a myth is notable.

With Byron Hero is replaced by Zuleika, Giaffir's daughter, and Leander was replaced by Selim. According to the interpretation by Byron Selim does not die in the sea, he dies in the battle for his sweetheart and falls in the sea, then his corps floats to the lady and the lady dies on the shore for the loss of her beloved.

In the poem, the literary alteration of the myth is given but if we remove the changed names and other changes, the main subject matter is still from the myth- devotion and self-sacrifice for love.

The story by Kuprin is a kind of new mythical story that is an attempt of transforming the myth itself: the characters by Kuprin Hero and Leander are young Greek sweethearts. By interfering an old shepherd, Satire, Hero commits adultery and the lad, reaching the shore shamefully falls asleep beside his beloved. None of the characters dies. The author interpreted the story heard from Anatolian Greeks.

It is vivid that in foreign texts the authors used the myth of "Hero and Leander" only for a love story and their interest was still interpretation of the old myth. As with the Georgian authors (G. Dochanashvili, T. Chiladze) "The Poem of the Lad from Tavparavani" is not only opening the love theme, it is a story developed on national basis.

With Guram Dochanashvili a banal story of two loved ones is just a struggle for inaccessible blissful happiness. Grandpa Giorgi tells the story and in the heart of the lad from Tavparavani the blissful love to an inaccessible lady is flaring by and by. It is search for "a queen of a word". In the story the light is coming to the lad as a dream, though is not seen in the story, as it is a dream. Maybe dream itself is the tower presented in the ballade represents striving to unreachable and all these are strengthened by fascinating Georgian folk love poems. In the text, a witch is seen which extinguishes the candle in order to devour the lad into darkness and though the lad from Tavparavani dies, the white candle is still lit in the tower. Its silent burning is Ascension.

The text revealed the theme of eternity and inaccessibility given by the source from the myth. That is why 10 years ago this text was included in the academic programs of literature of Secondary schools.

The play by Tamaz Chiladze is really a fairy-tale where as a night dream a romantic love to Apra (The lad from Tavparavani) arises in the woman living in a tower. Here real and unreal are so interlaced. The writer introduces Bakhuta, a lad in love with Nano in which the woman later recognizes the beloved from dreams. All these ends with the storyteller's words why the lad from Tavparavani died who decided to swim across the lake by millstone or a lifebelt (based on I. Maisuradze the researcher I. Merabishvili concerns a millstone as a round wooden lifebelt). 


\section{Conclusion}

Both fictions reveal the mythical vagueness of "The Poem of the Lad from Tavparavani", the reasons of its popularity. The folk source was a dream about hardly reachable. The fiction explained it so as well.

The interpretation of the Greek myth "Hero and Leander" in foreign texts and spreading "The Poem of the Lad from Tavparavani" in two Georgian fictions somehow strengthened the basis of the doubt of the researchers represented in the introduction. "The Poem of the Lad from Tavparavani" cannot be the parallel to the Greek myth or "a wandering subject matter". It does not give explanation to this but the fictions were able to clear it out as arisen from national origin.

As it was above mentioned this is only an attempt of stating the issue which requires deeper and thorough research.

\section{Bibliography}

1. Kurdovanidze T., Georgian Orally Transmitted Folklore. Tbilisi , 2012

2. Kotetishvili V., Folk Poetry, Tbilisi , 1961

3. Kalandadze G., Georgian Folk Ballade, Tbilisi, 1957

4. Janelidze D., The Folk Origin of Georgian Theatre, Tbilisi, 1949

5. Makhauri T.m Folklore Ethnographical Essays, Book III, Tbilisi, 2011

6. Kakabadze M., Georgian Folklore, 2008\#4 (XX)

7. Merabishvili I., Tselitsdeuli, Volume III, Kutaisi, 2011 